Restoration of montane fen meadows by mowing remains possible after 4-35 years of abandonment

Journal Article

Author(s):

Billeter, Regula; Peintinger, Markus; Diemer, Matthias

Publication date:

2007

Permanent link:

https://doi.org/10.3929/ethz-b-000006731

Rights / license:

In Copyright - Non-Commercial Use Permitted

Originally published in:

Botanica Helvetica 117(1), https://doi.org/10.1007/s00035-007-0743-9 


\title{
Restoration of montane fen meadows by mowing remains possible after 4-35 years of abandonment
}

\author{
Regula Billeter $^{1,2}$, Markus Peintinger ${ }^{1}$ and Matthias Diemer ${ }^{1}$ \\ ${ }^{1}$ Institute of Environmental Sciences, University of Zurich, Winterthurerstrasse 190, CH-8057 \\ Zurich \\ 2 Present address: Institute of Integrative Biology, ETH Zurich, Universitätsstrasse 18, \\ CH-8092 Zurich; e-mail: regula.billeter@env.ethz.ch
}

Manuscript accepted 23 January 2007

\begin{abstract}
Billeter R., Peintinger M. and Diemer M. 2007. Restoration of montane fen meadows by mowing remains possible after 4-35 years of abandonment. Bot. Helv. 117: 1-13.

The abandonment of management in Swiss fen meadows has reduced their plant species diversity and the fitness of some typical fen species. We examined whether the resumption of mowing can reverse these effects, and if so, which mechanisms are responsible for community change; we also tested whether restoration success depends on the duration since abandonment. Experimental mowing was applied to 15 montane fen meadows of NE Switzerland that had been abandoned for 4-35 years. After two years of mowing, plant species richness was $11 \%$ higher in mown plots $\left(2 \mathrm{~m}^{2}\right)$ than in fallow plots, approaching levels of neighbouring continuously managed fen meadows. In particular, experimental mowing significantly increased the number of fen indicator species $(+15 \%)$ as well as herbs and woody species (seedlings and saplings), while grass, sedge and rush species richness was not affected. Mowing had little effect on aboveground biomass, but strongly reduced litter mass $(-50 \%)$ and canopy height $(-20 \%)$. Seedling densities of two common species showed opposite responses to mowing: they increased in Carex davalliana and decreased in Succisa pratensis, approaching values of continuously mown fen meadows. Duration since abandonment had no significant effect on any of the variables. Our results demonstrate a rapid recovery of montane fen plant communities irrespective of the duration since abandonment (up to 35 years). We conclude that the restoration of pre-fallow plant community composition is likely to be successful if site conditions (hydrology, nutrient status) remain intact and if common habitat specialists are still present in the vegetation and/or seed bank.
\end{abstract}

Key words: Aboveground biomass, bryophytes, Carex davalliana, species richness, Succisa pratensis, wetland restoration. 


\section{Introduction}

The preservation and maintenance of biodiversity is a major concern world-wide (Ehrlich 1992; Hanski et al. 1995). In Central Europe, traditional forms of landscape management have led to semi-natural plant communities characterized by high levels of species richness and thus high conservation value, such as fen meadows or calcareous grasslands. Changes in agricultural practices and socio-economic trends currently threaten the existence of many of these communities via habitat fragmentation, melioration or abandonment (Fischer and Stöcklin 1997; Bakker and Berendse 1999). These management changes result in reductions of overall species richness as well as the loss of rare, endangered or formerly common habitat specialists (Stöcklin et al. 2000; Lienert et al. 2002). In calcareous fen meadows of Switzerland abandonment, i.e. the cessation of mowing, led to a $18 \%$ decline in plant species richness (Diemer et al. 2001). In some parts of Switzerland nearly $20 \%$ of all fen meadows are abandoned and this proportion is projected to increase. Hence the decline in plant biodiversity and in rare and endangered plant species, of which many occur in Swiss wetlands (Landolt 1991), is likely to continue or even accelerate in the future.

Fortunately, negative effects of abandonment can be reversed when management is restored in grasslands (Bobbink and Willems 1993; Zobel et al. 1996; Güsewell et al. 1998; Mortimer et al. 1998; Thorn 2000; Jensen and Meyer 2001; Maron and Jefferies 2001). In some fallows, however, the original species composition did not recover after mowing, or the change was exceedingly slow (Berendse et al. 1992; Stampfli and Zeiter 1999). It is unclear why restoration is successful in some instances and not in others. The lack of diaspores or of the original seed bank has been cited as major impediments to the recovery of the former species composition (Schrautzer et al. 1996; Bakker and Berendse 1999). This suggests that the success of restoration should strongly depend on the duration of abandonment, since many grassland species form short-lived seed banks (Maas 1988; Jensen 2004). If this is indeed the decisive determinant of restoration success, we should expect a strong decrease in the effectiveness of management with increasing duration. Therefore studies, which take into account the duration of abandonment and ideally compare abandoned sites of different age, are needed.

In this study we investigated the effects of resumed mowing on 15 calcareous fen meadows distributed throughout NE Switzerland, which have been abandoned 4 to 35 years ago. We focused on the following questions: Is there a rapid recovery of species richness of vascular plants and community productivity of vascular plant and bryophyte after re-initiation of management? How responsive are life history traits of common plant species of these fen meadows? Does restoration success decrease with increasing duration since abandonment?

\section{Materials and Methods}

\section{Field sites and treatments}

We examined the effects of management changes on plant species composition in montane calcareous fen meadows of NE Switzerland (Caricion davallianae alliance, $\mathrm{cf}$. Ellenberg 1986). These wetlands were traditionally mown every year in fall, resulting in high plant diversity (Peintinger et al. 2003). In a comparison of 27 fen meadows, the 
abandoned fen meadows, irrespective of the duration since abandonment, had on average $18 \%$ fewer species than mown controls $\left(27 \pm 1\right.$ vs. $33 \pm 1$ species $2 \mathrm{~m}^{-2}$, Diemer et al. 2001). This decline was due to a loss of herbs, grasses and fen indicator species. On the other hand, grass biomass increased nearly three-fold in fallows, contributing to a $21 \%$ increase in overall aboveground productivity relative to mown fen meadows (321 \pm 14 vs. $265 \pm 12 \mathrm{~g} \mathrm{~m}^{-2}$, Diemer et al. 2001).

In order to assess the effects of re-initiation of mowing, we randomly selected a subset of 15 abandoned fen meadows of differing ages (4 to 35 years since abandonment). For a detailed description of the sites, see Table 1. In each fen meadow, we randomly established four permanent plots $(2 \mathrm{~m} \mathrm{x} 1 \mathrm{~m}$ ) in May/June 1998 (see Diemer et al. 2001 for selection criteria). Two of these four plots per site were randomly assigned to either a control or an experimental mowing treatment, and the latter were mown for two consecutive field seasons (1998 and 1999) in mid-September, which is the traditional time of mowing. Both plant biomass and litter were removed after mowing.

Tab. 1. Designation and relevant characteristics of the study sites. "Age" refers to the duration of abandonment.

\begin{tabular}{lllllll}
\hline Canton & $\begin{array}{l}\text { Community } \\
\text { or region }\end{array}$ & Site & $\begin{array}{l}\text { Age } \\
\text { (years) }\end{array}$ & $\begin{array}{l}\text { Altitude } \\
(\mathrm{m} \text { a.s.l. })\end{array}$ & $\begin{array}{l}\text { Slope } \\
\left({ }^{\circ}\right)\end{array}$ & Exposure \\
\hline AR & Gais & Foren I & 12 & 1030 & 11.3 & $\mathrm{~N}$ \\
AR & Gais & Foren II & 10 & 1040 & 11.3 & $\mathrm{~N}$ \\
AR & Gais & Foren III & 33 & 1050 & 2.5 & $\mathrm{~N}$ \\
SG & St. Johann & Altschenchopf II & 25 & 1280 & 20.0 & $\mathrm{E}$ \\
SG & Ebnat Kappel & Rossweid & 20 & 1100 & 16.3 & $\mathrm{~N}$ \\
SG & Hemberg & Salomonstempel & 20 & 1020 & 13.8 & $\mathrm{~N}$ \\
SZ & Wägital & Bergliboden & 9 & 1050 & 11.3 & $\mathrm{~W}$ \\
SZ & Sattelegg & Hirzegg & 35 & 1250 & 12.5 & $\mathrm{~N}$ \\
SZ & Oberiberg & Bueffen I & 10 & 1240 & 13.8 & $\mathrm{~N}$ \\
SZ & Oberiberg & Bueffen II & 4 & 1200 & 16.3 & $\mathrm{~N}$ \\
SZ & Ibergeregg & Chappelried II & 7 & 1260 & 18.8 & $\mathrm{E}$ \\
SZ & Ibergeregg & Chappelried III & 30 & 1240 & 17.5 & $\mathrm{NW}$ \\
SZ & Alpthal & Langried & 30 & 1280 & 17.5 & $\mathrm{~W}$ \\
SZ & Alpthal & Rund Blätz I & 25 & 1270 & 15.0 & $\mathrm{~W}$ \\
SZ & Alpthal & Seiler/Zwäcken & 15 & 1320 & 18.8 & $\mathrm{NW}$ \\
\hline
\end{tabular}

\section{Data collection and measurements}

In late July or early August 2000, we recorded all vascular plant species in all four plots of each meadow. Species which we could not distinguish in their vegetative stages were treated as collective species. Total cover of vascular plants and bryophytes was estimated visually. Species with habitat specificity for Caricion davallianae communities were recorded using the indicator-species list derived from the Swiss wetland inventory (BUWAL 1990). In addition, we distinguished the following functional groups: a) herbs, b) grasses (Poaceae), c) rushes and sedges (Cyperaceae and Juncaceae) and d) woody species. Nomenclature follows Binz and Heitz (1990). Species richness was also recorded in late July/early August 1998, prior to the experiment. In 1998 , neither the total species richness nor the number of species in the four functional groups differed between the plots ( $p>0.5$, data not shown). Hence, no systematic 
differences with respect to plant composition occurred between control and experimental plots at the outset of the experiment.

Aboveground vascular plant and bryophyte biomass was sampled at peak standing crop in early August 2000 as estimates of community productivity. Within each plot, we cut the vegetation to ground level in a randomly selected subplot of $20 \times 20 \mathrm{~cm}$. Samples were separated into vascular plant biomass, litter, and bryophyte biomass. Plant biomass samples were sorted into three categories: a) herbs, b) grasses and c) sedges and rushes. The negligible fraction of woody plants was added to the herb samples. All samples were dried at $70{ }^{\circ} \mathrm{C}$ for $72 \mathrm{~h}$ and weighed.

Life history traits were investigated for two abundant plant species. Carex davalliana SM (Cyperaceae) is the dominant and characteristic clonal graminoid in these montane fen meadows and builds the matrix of these communities (Diemer et al. 2001). It is a dioecious species forming tussocks of male and female genets (occasionally hermaphrodite tussocks occur as well). Plants flower in April and produce on average 15 seeds per female inflorescence. Tussocks of this species can reach diameters of up to $30 \mathrm{~cm}$ and produce several hundred tillers.

Succisa pratensis Moench (Dipsacaceae) is one of the most common rosette herb species in fen meadows and moist grasslands. It is a long-lived, predominately nonclonal herb, which flowers in August/September. The rosette produces one to four flowering shoots that can grow up to one meter in height. One shoot produces on average one to three inflorescences. The flowers are pollinated by insects and seeds ripen in September/October.

Three individuals of each species where randomly chosen within each permanent plot in June 1998. The plants were marked with coloured wire and tags and surveyed in August 2000. We measured the following fitness traits for C. davalliana: total tiller number and number of flowering tillers in the tussock. From this we calculated the proportion of flowering tillers. For $S$. pratensis we determined the number of inflorescences per individual and the percentage flowering individuals. To measure recruitment and seedling establishment, we randomly selected five $10 \times 10 \mathrm{~cm}$ subplots in each plot and counted all seedlings of $C$. davalliana and S. pratensis in May/June 2000.

\section{Statistical analysis}

To test for differences between fallow and mown plots we applied an analysis of covariance with mowing treatment, age of abandonment, the interaction of mowing and age, as well as site as explaining variables. The mowing treatment and site were treated as nominal variables, while age of abandonment was fitted as a continuous variable. Because the effects of age and site were confounded (any age effect would result in differences among the 15 sites), we used Type I sums of squares in order to fit the effect of age before that of site; the site effect then represents differences among sites which remain after adjusting for age. Dependent variables were log- or arcsin-transformed if this was necessary to obtain a normal distribution of residuals. All analyses were done using SPSS version 11.0 for Macintosh. 


\section{Results}

The mowing treatment affected plant species composition, canopy structure and the fitness of individual species; these effects are reported in details below. In contrast, age of abandonment and the interaction between age and mowing treatment had no significant effect on any of the variables measured.

\section{Community composition of vascular plants}

In the year 2000, we recorded a total of 140 vascular plant species in the 60 studied $2 \mathrm{~m}^{2}$-plots (plus a few unidentified, vegetative graminoid and herb species). Of these species, 41 are indicator species of fen meadows (BUWAL 1990). Eighteen species (including two fen indicator species) grew exclusively in fallow plots, while 13 species (including three fen indicator species) occurred only in mown plots (Appendix 1).

The mean plant species richness per plot as well as the mean number of indicator species per plot increased significantly after the re-establishment of mowing $(+11 \%$, $p<0.01$ for total number, $+15 \%, p<0.01$ for indicator species; Fig. 1).

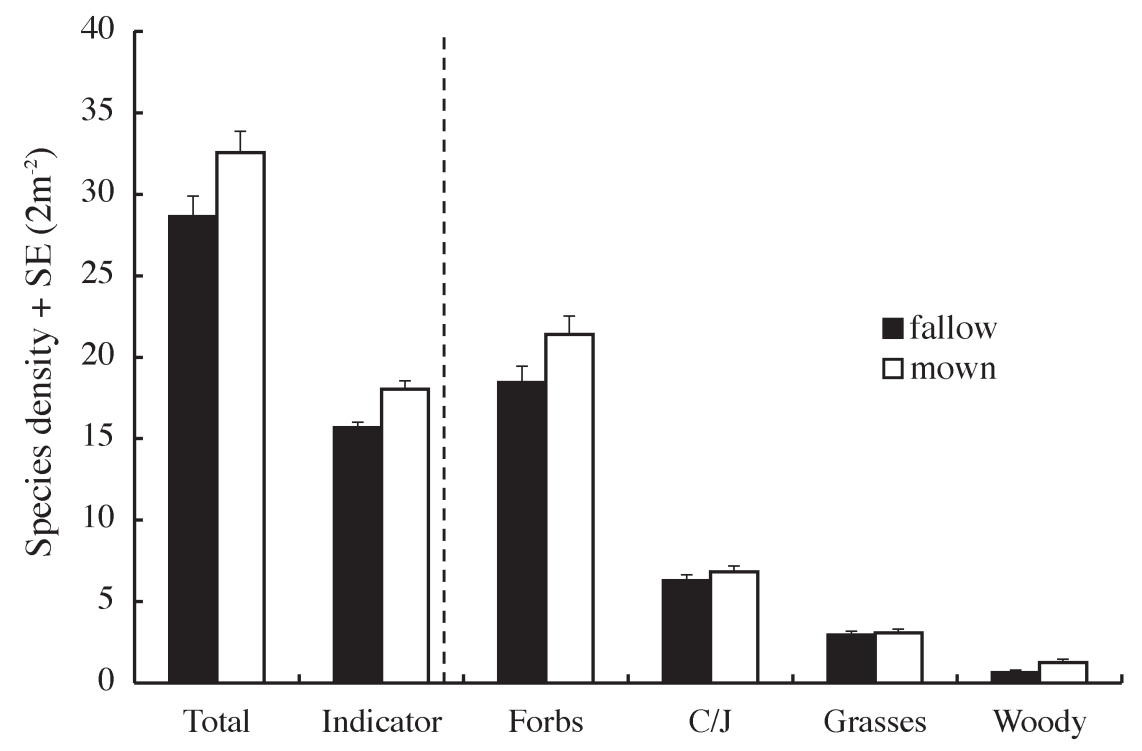

Fig. 1. Mean species richness per $2 \mathrm{~m}^{2}(+\mathrm{SE})$ of all vascular plant species, fen indicator species and different functional groups in abandoned and mown plots after two years of mowing.

Two indicator species profited considerably from mowing by substantially increasing their frequency: Parnassia palustris ( +10 plots) and Dactylorhiza maculata/majalis (+13 plots, Appendix 1). Other species that appeared to benefit from mowing were Briza media, Trifolium pratense (both +6 plots) and Abies alba $(+12$ plots). Some species were also negatively affected by the re-establishment of mowing, especially Carex flacca (-7 plots). 
Divided into functional groups, $66 \%$ of the 140 species were herbs, $10 \%$ grasses, $18 \%$ sedges and rushes and $6 \%$ woody species. The number of herbs as well as the number of woody species per plot (seedlings and saplings) increased after the re-establishment of mowing (Fig. 1; herbs: $p<0.05$; woody species: $p<0.01$ ) while the other two groups were not affected (grasses: $p=0.35$; sedges and rushes: $p=0.25$, Fig. 1 ).

\section{Biomass, litter and canopy structure}

Total living aboveground biomass decreased by $15 \%$ after mowing (fallow plots: 225.2 $\pm 15.2 \mathrm{~g} \mathrm{~m}^{-2}$; mown plots: $193.2 \pm 14.1 \mathrm{~g} \mathrm{~m}^{-2}$ ). However, this decrease was only marginally significant $(p=0.07)$. Herb biomass as well as biomass of sedges and rushes were not affected by mowing ( $p \geq 0.50$, Fig. 2 ), while grass biomass (mainly Molinia caerulea) tended to decrease in mown plots $(p=0.09$, Fig. 2$)$. Bryophyte biomass showed a marginally significant increase in mown plots $(p=0.10$, Fig. 2$)$. Litter mass was clearly affected by mowing and decreased by $45 \%$ in these plots $(p<0.001$, Figs 2,3$)$.

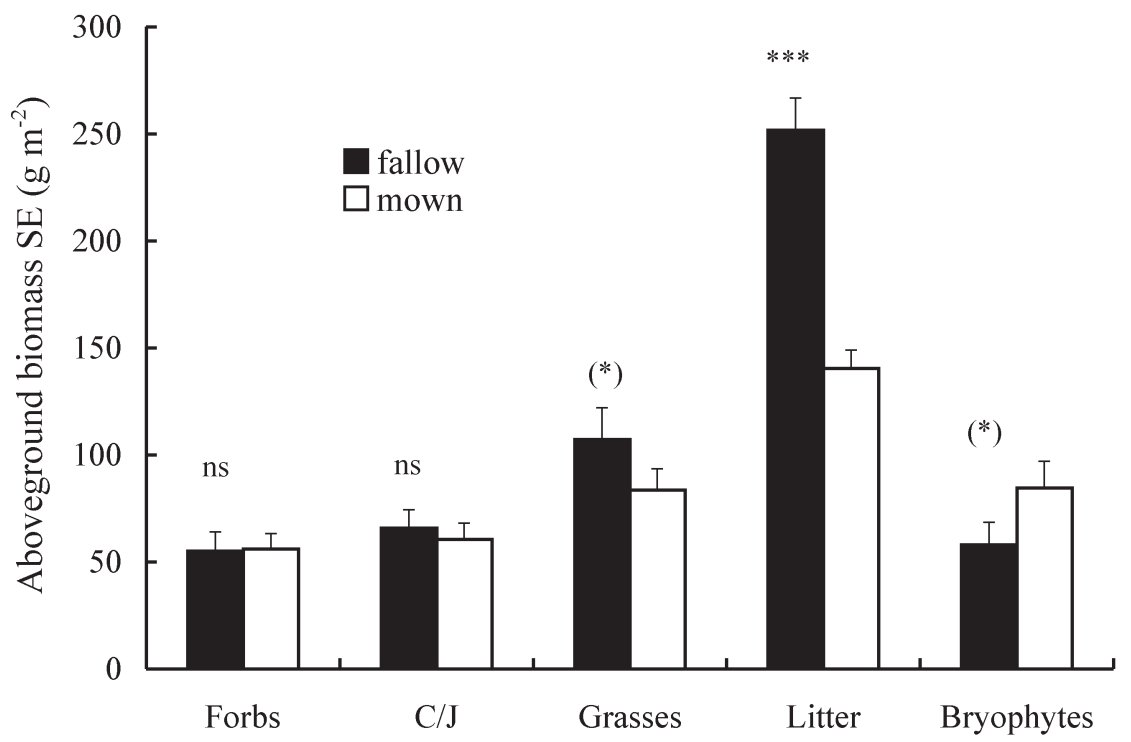

Fig. 2. Mean aboveground biomass $\left(+\mathrm{SE}, \mathrm{g} \mathrm{m}^{-2}\right)$ of the different functional groups and litter for abandoned and mown plots after two years of mowing. Significance: $\mathrm{ns}=$ not significant, $(*)=p<0.1, *=p<0.05, * *=p<0.01, * * *=p<0.001$.

The total cover of vascular plant species was on average $74 \%$ and did not change in mown relative to abandoned plots $(p>0.5)$, whereas the cover of bryophytes was $47 \%$ in fallows and increased to $60 \%$ after re-establishment of mowing $(p<0.05)$. 


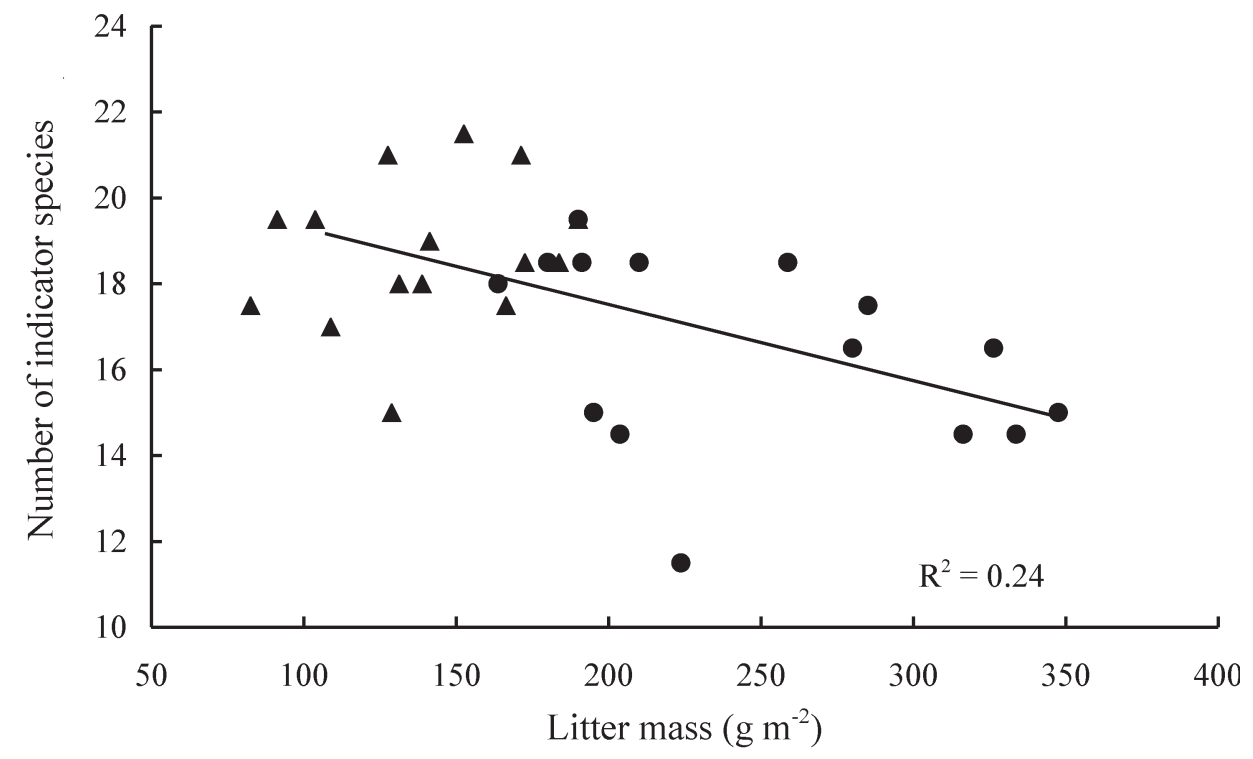

Fig. 3. Relationship between the number of indicator species per $2 \mathrm{~m}^{2}$ and litter mass $(\bullet=$ abandoned fens, $\boldsymbol{\Lambda}=$ mown fens).

Fitness of two common species

In Carex davalliana, the proportion of flowering tillers tended to increase in mown plots $(p=0.08$, Tab. 2). In Succisa pratensis, the number of inflorescences per plant tended to decrease in mown plots $(p=0.10$, Tab. 2$)$, whereas the percentage of flowering individuals did not change in response to mowing $(p=0.42$, Tab. 2$)$.

Tab. 2. Effects of the mowing treatment on phenotypic traits of Carex davalliana and Succisa pratensis in abandoned fen meadows (means $\pm \mathrm{SE}$ ). The significance of treatment effects was tested with two-way ANOVA (including sites as blocking factor, but no covariables).

\begin{tabular}{llll}
\hline Species and variable & Fallow & Mown & $P$ \\
\hline C. davalliana & & & \\
Proportion of flowering tillers & $0.12 \pm 0.02$ & $0.19 \pm 0.03$ & 0.079 \\
Seedling density $\left(\mathrm{dm}^{-2}\right)$ & $0.40 \pm 0.07$ & $1.49 \pm 0.24$ & $<0.001$ \\
S. pratensis & $38 \pm 7.18$ & $31 \pm 5.58$ & $\mathrm{~ns}$ \\
Percentage of flowering individuals & $1.82 \pm 0.33$ & $1.11 \pm 0.28$ & 0.10 \\
Inflorescences per plant & $1.04 \pm 0.17$ & $0.53 \pm 0.14$ & $<0.01$ \\
Seedling density $\left(\mathrm{dm}^{-2}\right)$ & &
\end{tabular}

The seedling density of both species was strongly affected by mowing. The seedling density of $C$. davalliana increased more than threefold in mown plots $(p<0.001$, Tab. 2), while that of $S$. pratensis decreased by $50 \%$ in mown plots $(p<0.01$, Tab. 2$)$. 


\section{Discussion}

Does mowing enhance plant diversity?

Although initial richness of the vegetation did not differ among plots in each fallow in 1998, we found a significant increase of the species richness in mown plots after merely two seasons of experimental treatment. This is in accordance with the findings of Wheeler and Giller (1982), Müller et al. (1992), Zobel et al. (1996), Güsewell et al. (1998), Thorn (2000) and Jensen and Meyer (2001). They all showed a clear increase in species richness after the re-establishment of mowing in previously abandoned wetlands. The mean species richness of our experimental plots (Fig. 1) was virtually identical to that of seven continuously mown fen meadows adjacent to our fallows (33.0 \pm 1.2 taxa per $2 \mathrm{~m}^{2}$, including $15.9 \pm 0.5$ fen indicator species; Diemer et al. 2001).

\section{Mechanisms of community change}

Abandoned and formerly mown fen meadows of NE Switzerland can be characterized by an enormous increase in litter biomass ( $>10$-fold) and a modest increase in aboveground biomass $(+21 \%)$ as well as a $50 \%$ increase in canopy height, relative to continuously mown fen meadows (Diemer et al. 2001). The build-up of litter in fallows leads to a drastic increase in shading, which increases competition for light, lowers soil and canopy temperatures, and reduces seed germination and seedling establishment (Bosshard et al. 1988). The negative relationship between litter mass and species richness is well established (Fig. 3, see also Carson and Peterson 1990; Xiong and Nilsson 1999), although Foster and Gross (1998) demonstrated that litter and aboveground biomass are largely substituable in their inhibitory effects.

Mowing produces lower and more open vegetation (Buttler 1992) and reverses the above-described effects. Especially indicator species and herbs appear to profit from these changes (Figs. 1 and 3). The increase of the orchid Dactylorhiza maculata can be attributed to dormancy since Tamm (1972) showed for closely related Dactylorhiza species that they can remain dormant during unfavourable conditions for several years. One indicator species that increased substantially in mown plots, Parnassia palustris, flowers early in the season. It might have been present in fallows, but only in a vegetative state, and expanded following the improved light regime after mowing. However, it is also possible that re-colonisation occurred in mown plots. Thorn (2000) and de Bruijn and Hofstra (1997) also observed that characteristic fen species were favoured by mowing. The fact that some woody species increased significantly in mown plots is not surprising (Fig. 1). Germination and recruitment of woody species is strongly constrained by litter (Xiong and Nilsson 1999). After mowing, germination of dormant and freshly shed seeds occurs, although continuous mowing will prevent woody plant establishment.

The role of aboveground biomass was less clear than that of litter. In our experimental plots, aboveground biomass decreased by $15 \%$ on average, but this response varied considerably among sites. Correspondingly, in a short-term study Güsewell et al. (1998) found no consistent differences in aboveground biomass between mown and unmown plots. In contrast, Müller et al. (1992) described a substantial decrease in aboveground biomass after mowing; the difference may be due to the greater productivity of their sites compared to ours. 
Of the functional groups, only grasses responded significantly to mowing (Fig. 3). Grass biomass tended to decrease in mown plots, yet this decrease was not associated with a decrease in grass species richness (Fig. 1). Presumably, tussock size and/or tiller biomass of the abundant Molinia caerulea decreased after mowing, as observed by Diemer and Pfadenhauer (1987). Similarly, the increase in herb species richness was not reflected in enhanced herb biomass after two years.

Bryophyte biomass increased by nearly $30 \%$ in mown plots. Similar but less pronounced responses were observed by Huhta et al. (2001). Bergamini et al. (2001) found that bryophyte biomass decreased with increasing vascular plant biomass, indicating that bryophyte growth is light-limited. Moreover, Peintinger and Bergamini (2006) showed for sites in the same region that the bryophyte biomass was twofold lower in abandoned than in mown fens. The observed tendency of enhanced bryophyte biomass in our study corresponds to a $13 \%$ increase in the cover of bryophytes after mowing. In mown plots bryophytes clearly profit from the removal of litter and from the improved light conditions, as both variables were correlated with litter mass.

\section{Responses of Carex davalliana and Succisa pratensis}

We found a clear impact of mowing on seedling density of both study species. While seedling density of $S$. pratensis declined, density of $C$. davalliana seedlings increased threefold in mown plots. Billeter et al. (2003) observed the opposite reaction of these two species in response to abandonment. They concluded that litter inhibits germination of $C$. davalliana, as suggested by several authors (Maas 1988; Bosshard et al. 1988; Jensen 1997). However, not only litter removal, but also the increase in the proportion of flowering tillers of $C$. davalliana (Tab. 2) presumably enhanced seedling density in mown plots (Diemer and Pfadenhauer 1987).

The late-flowering S. pratensis, on the other hand, profited from unhindered flowering and seed ripening in fallows. Seedling establishment was clearly enhanced under shady conditions (Billeter et al. 2003). Mowing lowered reproductive success and led to a decrease in the number of inflorescences (Tab. 2), which further decreased seed set. This is in contrast to the study by Stammel et al. (2006). They found either no effect of management or even lower germination rates for $S$. pratensis in abandoned fens. However, they did an inseeding experiment with a fixed number of seeds $(25 / 50$ seeds). $S$. pratensis is a late-flowering species. Seed availability of late flowering species may be reduced under a mowing regime, due to prevention of seed ripening and dispersal (Coulson et al. 2001; Dumontier et al. 1996). By sowing a fixed number of seeds, the advantage of abandonment - unhindered ripening and dispersal of seeds - could not come into play in the experiment of Stammel et al. (2006). This suggests that not germination and establishment are most affected by mowing, but seed ripening and dispersal.

\section{Does the duration of abandonment matter?}

The duration of abandonment did not influence any of the variables measured, nor was there any interaction between the treatment and fallow age. This indicates that observed changes during the first 35 years of abandonment are not time-dependent and largely reversible. This is in accordance with the findings of Diemer et al. (2001) and Peintinger and Bergamini (2006), who also observed no evidence of successional trajectories in their fallow fen meadows, which formed the basis of the study presented here. Moreover, Kotiluoto (1998) and Thorn (2000) showed that it is possible to restore 
fallow fens and meadows, which were abandoned 20 to 30 years ago. Therefore, the age of a fallow does not seem to pose a serious constraint for restoration via mowing, at least in the first 35 years of abandonment, provided that invasion of woody species is constrained (Zobel et al. 1996; Dzwonko and Loster 1998), site conditions (hydrology, nutrient status) remain intact and common habitat specialists are still present in the vegetation and/or seed bank.

\section{Implications for conservation}

It is possible to restore plant communities of montane fallow fen meadows by reestablishing the traditional mowing regime (Thorn 2000), at least in the first 35 years of abandonment. For lowland fen meadows or mesic grasslands the maximum duration that still allows successful restoration is probably shorter, since succession, particularly the invasion of woody plants may be faster (Fossati and Patou 1989; Zobel et al. 1996).

However, mowing may impair recruitment of late blooming herbs (e.g. S. pratensis) and species richness of invertebrates such as butterflies (Balmer and Erhardt 2000). To enhance reproduction of late blooming herbs as well as species richness of insects, intermittent fallow periods may be desirable. Therefore, for conservation purposes, the creation of varying managment regimes (analogous to Pöyry et al. 2004, 2005) such as mowing every second year (Diemer and Pfadenhauer 1987) or mosaics of fallow and mown patches could be optimal strategies to maintain the plant species richness and conservation value of abandoned calcareous fen meadows.

\section{Zusammenfassung}

Wir untersuchten, wie sich die Wiederaufnahme der Mahd in verbrachten Flachmooren auf die Artenvielfalt und Biomasse Produktion von Pflanzen und auf die Fortpflanzung von zwei typischen Flachmoor-Arten auswirkt. Wir wählten dazu 15 montane Flachmoore aus, die seit 4-35 Jahren verbracht waren. In diesen Mooren wurden zwei von vier $2 \mathrm{~m}^{2}$-Flächen experimentell wieder gemäht. Nach zwei Jahren Mahd stieg die Artenvielfalt um $11 \%$ und erreichte ähnliche Werte wie kontinuierlich bewirtschaftete Flachmoore. Insbesondere die Anzahl Indikator-Arten für Flachmoore stieg signifikant an (15\%), aber auch Kraut- und Holzpflanzen (Keimlinge und Jungpflanzen) konnten profitieren. Die Mahd hatte nur einen geringen Einfluss auf die oberirdische Biomasse, reduzierte jedoch sowohl die Streuschicht $(-50 \%)$ als auch die Vegetationshöhe (-20\%) stark. Die Keimlingsdichten von zwei typischen Flachmoorarten reagierten gegensätzlich auf die Mahd: für Carex davalliana nahm die Dichte zu, für Succisa pratensis nahm sie ab. Die Werte näherten sich auch hier den Werten von kontinuierlich bewirtschafteten Flachmooren. Die Dauer der Verbrachung hatte keinen signifikanten Einfluss auf alle gemessenen Variabeln. Unsere Resultate zeigen, dass die Pflanzengesellschaften von verbrachten Flachmooren sich sehr schnell erholen können, unabhängig vom Alter der Brache (4-35 Jahre). Die Wiederherstellung der ursprünglichen Pflanzengesellschaften (wie vor der Verbrachung) ist mit grosser Wahrscheinlichkeit erfolgreich, wenn die Standortbedingungen (Hydrologie, Nährstoffe) intakt sind und wenn die typischen, spezialisierten Flachmoor-Arten noch vorhanden sind, in der Vegetation und/oder in der Samenbank. 
We thank O. Schelske for his help in the field. A special thanks goes to the farmers, owners and cantonal authorities, who allowed us to work on their fen meadows. This work was supported by a grant from the Swiss National Science Foundation (No. 31-50669.97 to M. D.)

\section{References}

Balmer O. and Erhardt A. 2000. Consequences of succession on extensively grazed grassland for Central European butterfly communities: Rethinking conservation practices. Conserv. Biol. 14: 746 - 757.

Bakker J.P. and Berendse F. 1999. Constraints in the restoration of ecological diversity in grassland and heathland communities. Trends Ecol. Evol. 14: 63 - 68.

Berendse F., Oomes M.J.M., Altena H.J. and Elberse W.T. 1992. Experiments on the restoration of species-rich meadows in the Netherlands. Biol. Conserv. 62:59-65.

Bergamini A., Pauli D., Peintinger M. and Schmid B. 2001. Relationships between productivity, number of shoots, and number of species in bryophytes and vascular plants. J. Ecol. 89: $920-929$.

Billeter R. , Hooftman D.A.P. and Diemer M. 2003. Differential and reversible responses of common wetland species to abandonment. Appl. Veg. Sci. 6: 3-12.

Binz A. und Heitz C. 1990. Schul- und Exkursionsflora für die Schweiz mit Berücksichtigung der Grenzgebiete, $19^{\text {th }}$ ed. Schwabe und Co., Basel.

Bobbink R. and Willems J.H. 1993. Restoration management of abandoned chalk grassland in the Netherlands. Biodivers. Conserv. 2: $616-626$.

Bosshard A., Andres F., Stromeyer S. und Wohlgemuth Th. 1988. Wirkung einer kurzfristigen Brache auf das Oekosystem eines anthropogenen Kleinseggenriedes - Folgerungen für den Naturschutz. Bull. Geobot. Inst. ETH 54: 181 - 220.

Buttler A. 1992. Permanent plot research in wet meadows and cutting experiment. Vegetatio 103: 113 - 124 .

BUWAL 1990. Inventar der Flachmoore von nationaler Bedeutung. Bundesamt für Umwelt, Wald und Landschaft (BUWAL), Bern.

Carson W.P. and Peterson C.J. 1990. The role of litter in an old-field community: impact of litter quantity in different seasons on plant species richness and abundance. Oecologia 85: $8-13$.

Coulson S.J., Bullock J.M., Stevenson M.J. and Pywell R.F. 2001. Colonization of grassland by sown species: Dispersal versus microsite limitation in response to management. J. Appl. Ecol. 38: $204-216$.

De Bruijn O. and Hofstra J. 1997. Return of rare plant species to the Boddenbroek after restoration management. De Levende Natuur 98: 289 - 295.

Diemer M.W. and Pfadenhauer J. 1987. Effects of differential defoliaton on shoot growth, density and phytomass of three graminoids in a calcareous fen. Oikos 50:183-190.

Diemer M., Oetiker K. and Billeter R. 2001. Abandonment alters community composition and canopy structure of Swiss calcareous fens. Appl. Veg. Sci. 4: 237 - 246.

Dumontier M., Verlinden A., Beeckman H. and Mijnbrugge K. 1996. Effects of harvesting dates and frequencies on above and below-ground dynamics in Belgian wet grasslands. Ecoscience 3: 190 - 198.

Dzwonko Z. and Loster S. 1998. Dynamics of species richness and composition in a limestone grassland restored after tree cutting. J. Veg. Sci. 9: 387 - 394.

Ehrlich P.R. 1992. Population biology of checkerspot butterflies and the preservation of global biodiversity. Oikos 63: $6-12$.

Ellenberg H. 1986. Vegetation Mitteleuropas mit den Alpen in ökologischer Sicht. Ulmer, Stuttgart.

Fischer M. and Stöcklin J. 1997. Local extinction of plants in remnants of extensively used calcareous grasslands 1950 -1985. Conserv. Biol. 11: 727 - 737. 
Fossati J. and Patou G. 1989. Vegetation dynamics in the fens of Chautagne (Savoie, France) after the cessation of mowing. Vegetatio 85: $71-81$.

Foster B.L. and Gross K.L. 1998. Species richness in a successional grassland: effects of nitrogen enrichment and plant litter. Ecology 79: 2593 - 2602.

Güsewell S., Buttler A. and Klötzli F. 1998. Short-term and long-term effects of mowing on the vegetation of two calcareous fens. J. Veg. Sci. 9: $861-872$.

Hanski I., Clobert J. and Reid W. 1995. Ecology of extinctions. - In: Heywood V.H. (ed.). Global biodiversity assessment. Cambridge University Press, $232-245$.

Huhta A.-P., Rautio P. and Tuomi J. 2001. Restorative mowing on an abandoned semi-natural meadow: short-term and predicted long-term effects. J. Veg. Sci. 12: $677-686$.

Jensen K. 1997. Vegetationsökologische Untersuchungen auf nährstoffreichen Feucht-grünland-Brachen. Sukzessionsverlauf und dynamisches Verhalten von Einzelarten. Feddes Repert. 108: $603-625$.

Jensen K. 2004. Dormancy patterns, germination ecology, and seed-bank types of twenty temperate fen grassland species. Wetlands 24: $152-166$.

Jensen K. and Meyer C. 2001. Effects of light competition and litter on the performance of Viola palustris and on species composition and diversity of an abandoned fen meadows. Plant Ecol. 155: 169 - 181

Kotiluoto R. 1998. Vegetation changes in restored semi-natural meadows in the Turku archipelago of SW Finnland. Plant Ecol. 136: 53 - 67.

Landolt E. 1991. Gefährdung der Farn- und Blütenpflanzen in der Schweiz mit gesamtschweizerischen und regionalen Roten Listen. EDMZ, Bern.

Lienert J., Fischer M. and Diemer M. 2002. Local extinctions of the wetland specialist Swertia perennis L. (Gentianaceae): a revisitation study based on herbarium records. Biol. Conserv. 103: $65-76$.

Maas D. 1988. Keimung und Etablierung von Streuwiesenpflanzen nach experimenteller Ansaat. Nat. Landsch. 63: $411-415$.

Maron J.L. and Jefferies R.L. 2001. Restoring enriched grasslands: effects of mowing on species richness, productivity, and nitrogen retention. Ecol. Appl. 11: 1088 - 1100.

Mortimer S.R., Hollier J.A. and Brown V.K. 1998. Interactions between plant and insect diversity in the restoration of lowland calcareous grasslands in southern Britain. Appl. Veg. Sci. 1: $101-114$.

Müller J., Rosenthal G. und Uchtmann H. 1992. Vegetationsveränderungen und Ökologie nordwestdeutscher Feuchtgrünlandbrachen. Tuexenia 12: 223 - 244.

Peintinger M., Bergamini A. and Schmid B. 2003. Species-area relationships and nestedness of four taxonomic groups in fragmented wetlands. Basic Appl. Ecol. 4: 385 - 394.

Peintinger M. and Bergamini A. 2006. Community structure and diversity of bryophytes and vascular plants in abandoned fen meadows. Plant Ecol. 185:1 - 17.

Pöyry J., Lindgren S., Salminen J. and Kuussaari M. 2004. Restoration of butterfly and moth communities in semi-natural grasslands by cattle grazing. Ecol. Appl. 14: $1656-1670$.

Pöyry J., Lindgren S., Salminen J. and Kuussaari M. 2005. Responses of butterfly and moth species to restored cattle grazing in semi-natural grasslands. Biol. Conserv. 122: 465-478.

Schrautzer J., Asshoff M. and Muller F. 1996. Restoration strategies for wet grasslands in northern Germany. Ecol. Eng. 7: 255 - 278

Stammel B., Kiehl K. and Pfadenhauer J. 2006. Effects of experimental and real land use on seedling recruitment of six fen species. Basic Appl. Ecol. 7: 334 - 346.

Stampfli A. and Zeiter M. 1999. Plant species decline due to abandonment of meadows cannot easily be reversed by mowing. A case study from the southern Alps. J. Veg. Sci. 10: 151 164.

Stöcklin J., Ryf M. and Fischer M. 2000. Small size of remnants of nutrient-poor calcareous grassland (Mesobromion) in the Swiss Jura puts many plant species at the risk of local extinction. Z. Ökol. Nat.schutz 9: $109-118$.

Tamm C.O. 1972. Survival and flowering of some perennial herbs. Oikos 23: $23-28$. 
Thorn M. 2000. Auswirkungen von Landschaftspflegemassnahmen auf die Vegetation von Streuwiesen. Nat. Landsch. 75: $64-73$.

Wheeler B.D. and Giller K.E. 1982. Species richness of herbaceous fen vegetation in Broadland, Norfolk in relation to the quantity of above-ground plant material. J. Ecol. 70: 179-200.

Xiong S. and Nilsson C. 1999. The effects of plant litter on vegetation: a meta-analysis. J. Ecol. 87: 984 - 994.

Zobel M., Suurkask M. and Rosén E. 1996. The dynamics of species richness in an experimentally restored calcareous grassland. J. Veg. Sci. 7: $203-210$.

\section{Electronic Appendix}

Appendix 1. Absolute frequency of all vascular plant species found in fallow and mown plots of 15 abandoned fen meadows (IS: fen indicator species according to BUWAL 1990). Species are listed according to the changes in absolute frequency after mowing (total $\mathrm{n}=30$ ). Nomenclature follows Binz and Heitz (1990).

This Appendix can be downloaded at http:// www.birkhauser.ch/BH 